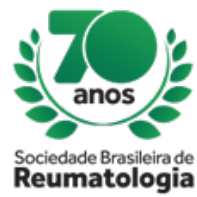

\title{
CAN POLYARTICULAR ULTRASOUND PREDICT THE DEVELOPMENT OF PSORIATIC ARTHRITIS OVER TIME? - A PROSPECTIVE STUDY WITH 4 YEARS OF FOLLOW-UP
}

\author{
BARBARA CARVALHO KLEMZ (UNIVERSIDADE FEDERAL DE SÃO PAULO, SÃO PAULO, SP, Brasil), KARINE \\ RODRIGUES LUZ (UNIVERSIDADE FEDERAL DE SÃO PAULO, SÃO PAULO, SP, Brasil), ADRIANA MARIA \\ PORRO (UNIVERSIDADE FEDERAL DE SÃO PAULO, SÃO PAULO, SP, Brasil), POLIANNA OLIVEIRA MATOS \\ SOARES (MED NOBILLI CLINIC, SÃO PAULO, SP, Brasil), MARCELO MEDEIROS PINHEIRO (UNIVERSIDADE \\ FEDERAL DE SÃO PAULO, SÃO PAULO, SP, Brasil)
}

\section{BACKGROUND}

Articular involvement is observed in about $30 \%$ of patients with psoriasis. However, no complementary examination is sufficient to predict the risk of developing joint involvement over time.

Objectives: To evaluate the predictive value of polyarticular ultrasound (US) in patients with psoriasis, asymptomatic from the articular point of view, after 4 years of follow-up.

\section{MATERIALS AND METHODS}

A total of 56 patients with psoriasis (Ps) and 30 healthy controls were included in this case-control study with 2 assessments (initial time and 4 years after). Patients with previous diagnosis of any rheumatic disease were excluded. They were evaluated by dermatologist and rheumatologist to evaluate the outcomes of activity and severity of cutaneous and articular outcomes, including PASI, nail dystrophy, number of painful and swollen joints, enthesis and dactylitis. All of them performed polyarticular US by another observer, enabled in image and blinded to the other assessments.

\section{RESULTS}

In the first evaluation, the US aggregated diagnosis of subclinial synovitis in $41 \%$ of patients with Ps, including findings of synovitis, erosion, tenosynovitis, enthesitis $(P<0.02)$, especially in the lower limbs (39.6\% vs. 9.3\% of controls). Moreover, the thickness of the tendons was higher in patients with Ps than healthy controls, regardless of the nail dystrophy $(p<0.001)$. After 4 years, the GUESS score (Glasgow Ultrasound Enthesitis Scoring System) was able to predict the onset of psoriatic arthritis (PsA), regardless of the nail dystrophy $(P<0.03$ ), as well as the history of dactylitis (accuracy of $89 \%$, specificity of $94 \%$ and $\mathrm{HR}=17.2 ; 95 \% \mathrm{Cl} 2.2-35.7 ; \mathrm{p}=0.017$ ) and paratendinitis of the extensor II of the toes (sensitivity of $83 \%$, specificity of $68 \%$ and accuracy of $69.6 \%$ ), after adjustments for confounding variables.

\section{CONCLUSION}

In patients with psoriasis, our results showed that the 2 main factors associated with the emergence of PsA, over 4 years, were the self-reported dactylitis and the US findings of the lower limbs, assessed by the GUESS score. Moreover, the higher frequency of paratendinitis of the I and II extensor of the toes was the unpublished finding of this study. 